\title{
Impact Factors Affecting the Flights of China Southern Airline: Based on "Belt and Road" Perspective
}

\author{
Song Yanan \\ School of Business \\ Macau University of Science and Technology \\ Macau, China \\ ynsong@must.edu.mo
}

\begin{abstract}
This paper analyzes the impact factors of flights of China Southern Airline in 36 Belt and Road countries from 2004 to 2017 by using the Gravity model. The results show that population, GDP of destination countries, trade, geographic distance and culture integration between China and destination countries play significant impact on China Southern Airline launching a new flight route decision which both are the results of market demand and tie in with the national policies. The "Belt and Road Initiatives" have provided great opportunities for China companies and other countries, especially companies in infrastructure and transportation industries. The results might have some implications on these companies and also build up the competitive capabilities.
\end{abstract}

Keywords_Flights; Airline; Belt and Road; Gravity model

\section{INTRODUCTION}

In 2015, China put forward the "Vision and proposed actions outlined on jointly building Silk Road Economic Belt and 21st-Century Maritime Silk Road" (hereinafter referred to as "Belt and Road") and hoped that the strategy of "Belt and Road" will promote and deepen the political, Economic, trade and other aspects of $\mathrm{i}$ exchanges and cooperation with countries along the Belt and Road. The connectivity of infrastructure construction is the basis for all countries to strengthen their ties and reduce the trade costs. It is also the primary task and the key development direction for the "Belt and Road" strategy. With the development of global economic and regional economic integration, inter-regional and international air passenger and cargo transport both have different degrees of growth. In particular, the far-end passenger transport among all countries is particularly prominent and has gradually become an important means of social communication. The rapid development of air transport industry is extremely beneficial to enhancing the strength of economic and trade ties at the district level and can strengthen inter-regional international economic cooperation. To explore the connection of air transport links between various countries along the Belt and Road and air passenger transport for China in the international community is conducive to the construction and optimization of the hub layout for the aviation network in the "Belt and Road Initiative." Not only that, but also it will have profound implications for enhancing economic cooperation among the regions.

China Southern Airline is China's largest transport airlines which has the most developed route network, the largest annual passenger volume. It occupies the first place in Asia and the third in the world in terms of passenger capacity and ranks the first in Asia and fourth in the world in terms of fleet size. It is the first airline in the world to operate both the Airbus A380 and the Boeing 787. It is the most popular airline in China with the largest airline network and the largest annual passenger volume. At present, there are 91 routes along the Belt and Road countries, accounting for $46.3 \%$ of the international flights. There are 164 "Belt and Road" routes including Japan and South Korea, which account for $86.1 \%$ of the international flights of the company. Among the "Belt and Road" countries, there are already 25 countries with routes that are mainly concentrated in Southeast Asia and Central Asia countries. This paper will analyze the impact factors of flights of China Southern Airline in 36 Belt and Road countries by using the Gravity model.

\section{Methodology}

The gravity model of international trade was first formulated by Dutch economist Jan Tinbergen in 1962 and since then a large body of work regarding the theoretical and practical considerations has been written. Initially, the model came under criticism for its lack of theoretical underpinning, but authors such as Bergstrand have been able to marry more typical consumer demand theory with the gravity framework and show that the gravity equation is a reduced form of Heckster-Ohin demand models. In fact, the model can be backed up with a variety of underlying theoretical structures.

The basic gravity model has been an extremely successful empirical representation of international trade flows. The basic model put forward by Tinbergen posits that the flow of trade between two countries is a function of the GDP of each and the distance between them. Equation 2.1 takes the same form as Newtonian gravity, but replaces mass with economic interpretation: GDP. Tinbergen's flow was the value traded goods, but many types of flows may be represented here. Notable is the addition of $\eta_{i j}$ which represents an error term 
that is independent and identically distributed economic interpretation: GDP. Tinbergen's flow was the value traded goods, but many types

$$
\text { Flow }_{i j}=\alpha \frac{G D P_{i}^{\beta_{1}} \times G D P_{j}^{\beta_{2}}}{D i s \tan c e_{i j}^{\beta_{3}}} \eta_{i j}
$$

In order to estimate eq. (1) using OLS, Tinbergen applied a simple log-linearization, see eq. (2) In this way the parameters $\alpha, \beta 1, \beta 2$ and $\beta 3$ can be determined. Because the equation takes the natural logarithm of both sides, the resulting coefficients can be interpreted as elasticities, which are conveniently unit-free.

$$
\ln \text { Flow }_{i j}=\ln \alpha+\beta_{1} \ln G D P_{i}+\beta_{2} \ln G D P_{j}+\beta_{3} \ln D i s \tan c e_{i j}+\eta_{i j}
$$

Using the above estimation it has been shown that there is a positive correlation between GDP and the flow of exports. Distance is negatively correlated with flows, and there are many dimensions to distance that have been shown to be important. For example DeGroot et al show the importance of cultural distance using Hoftetters metrics, and in Guiso et al the importance of common language is clear. Other papers commonly look at the effect of trade agreements or currency unions. Important to note that often the causal variable of interest is one of these bilateral or multilateral variables [1].

In aviation, Gravity model is also a popular tool for determining the potential for flights markets. Many of the same issues regarding the gravity model of trade still apply in the case of aviation. For analyzing the factors affecting airline flights, the Gravity models can be derived from other selected economic or social supply variables by assume that air travel supports other targeted activities such as business or vacation trips (O’Connor, 1982)[2]. In general, these variables describe the economic activities and geographical characteristics of the areas around the airports and the routes involved (JorgeCalderón, 1997) [3]. The most commonly used factors are income and the population of the districts. Several economic factors are also measured (Doganis, 2004) [4]. Other variables that have been used are income distribution, percentage of educated population, number of full-time employees, type of city, employment composition, structure of the local production sector, and economic, political and cultural relationships between two countries (Russon and Riley, 1993) [5]. An important factor affecting flight demand is the distance between cities which has two conflicting effects: increasing distance leads to lower social and commercial interactions but longer distances increase the competitiveness of air transport compared to other transportation modes (Jorge-Calderón, 1997) [6]. And variables describing the general economic activity and geographical characteristics of city-pairs instead of variables describing air service characteristics are also used in analysis for measurement of the flight demand(Grosche, Rothlauf and Heinzl, 2007) [7]. And there is also some research to investigate the key determining factors for China's international air freight flow. They also used gravity model by extending the models developed in Matsumoto (2004, 2007)[8-9], Yamaguchi (2008) [10]and Hwang and Shiao (2011)[11].
A simple formulation of a gravity model for human spatial interaction used for the prediction travel demand between two cities $\mathrm{i}$ and $\mathrm{j}$ is

$$
V_{i j}=k \cdot \frac{\left(A_{i} A_{j}\right)^{\alpha}}{\left(d_{i j}\right)^{\gamma}}
$$

where $V_{i j}$ is the passenger volume between $\mathrm{i}$ and $\mathrm{j}, A_{i}$ and $A_{j}$ are attraction factors of $\mathrm{i}$ and $\mathrm{j}, d_{i j}$ is the distance between the cities, and $k$ is a constant. $\gamma$ is a parameter that controls the influence of the distance on travel demand and $\alpha$ controls the influence of the attraction factors. Usually, the attraction and deterrence is expressed not only by a single variable but by a combination of various factors. This undirected gravity model can be extended to a directed model if $V_{i j}$ measures directed passenger flows from i to $\mathrm{j}$. Then, separate variables represent travel production (push) factors the originating city and travel attraction (pull) factors Ai $\alpha$ of the destination city. This distinction is sometimes only made by allowing the variables to have different parameter values for the origin and destination city while using the same variables for both.

So for this paper, an augmented Gravity model is

$$
\begin{aligned}
& \ln F L_{i j}=c+\beta_{1} \ln P O P_{i t}+\beta_{2} \ln G D P_{i t}+\beta_{3} \ln T R D_{i t}+\beta_{4} \ln D I S_{i} \\
& +\beta_{5} C u l_{i}+\varepsilon_{i t}
\end{aligned}
$$

where $F L_{i t}$ is total flights between China and country i of China Southern Airline; $P O P_{i t}$ is the population of country i; $G D P_{i t}$ is the gross domestic production of country $\mathrm{i} ; T R D_{i t}$ is the trade volume between China and country $\mathrm{i}$; $D I S_{i}$ is the geographical distance between China and country $\mathrm{i}$; $C U L_{i}$ is the dummy variable showing China whether sharing the same culture with country i.

\section{DATA}

China International Trade Institute released a report in August 2015, identified 65 countries along the Belt and Road that will be participating in the Initiatives [12]. Together, the countries along the Belt and Road will create an "economic cooperation area" that stretches from the Western Pacific to the Baltic Sea. China Southern Airlines launched 179 routes in 69 cities in 36 countries and regions along the "One Belt and One Road", including 34 new routes, with a total flight volume of 36,423 flights carrying a total of 4,745,000 passengers (excluding Xiamen Airlines) to further consolidate The "Belt and Road" as a major air carrier status. So the data set of this study consists of panel observations covering the period from 2004 to 2017, including 36 Belt and Road countries. The flight data collect from China Southern Airlines, the rest of the data collect from UN database.

Recent literature suggests that panel-based unit root tests have higher power than unit root tests based on individual time series. Many researchers believe that it is prudent to check for unit roots in each of the time series used to estimate a model. This study conducted tests raised by Levin, Lin and 
Chu (2002) [13], Im, Pesaran and Shin (2003)[14], Fishertype tests using ADF and PP tests (Maddala and $\mathrm{Wu}$ (1999)[15].

TABLE I. PANEL UNIT RoOT TEST

\begin{tabular}{|l|l|l|l|l|}
\hline & $\begin{array}{c}\text { Levin, } \\
\text { Lin \& } \\
\text { Chu }\end{array}$ & $\begin{array}{c}\text { Im, Pesaran } \\
\text { and Shin W- } \\
\text { stat }\end{array}$ & $\begin{array}{c}\text { ADF - } \\
\text { Fisher Chi- } \\
\text { square }\end{array}$ & $\begin{array}{c}\text { PP - Fisher } \\
\text { Chi-square }\end{array}$ \\
\hline $\ln \mathrm{V}$ & $0.000^{* *}$ & 0.025 & 0.000 & 0.000 \\
\hline $\ln \mathrm{POP}$ & $0.000^{* *}$ & 0.999 & 0.003 & 0.000 \\
\hline $\ln \mathrm{TRD}$ & $0.000^{* *}$ & 0.427 & 0.471 & 0.401 \\
\hline $\ln \mathrm{GDP}$ & $0.000^{* *}$ & 0.835 & 0.388 & 0.000 \\
\hline $\ln \mathrm{DIS}$ & $0.010^{* *}$ & 0.984 & 0.996 & 0.991 \\
\hline
\end{tabular}

Unit root tests of all series show the rejection of null hypothesis in level form in the auto-regression representation of each variable by using Levin, Lin and Chu (2002) test.

\section{EMPIRICAL RESULTS}

When creating a regression model of panel data, the first step is to determine the effects of the model, including mixing effects, fixed effects, and random effects. The F-test and Hausman test are then used to determine the model effect. The statistic of Cross-Session F-test was 30.3866 which was significant at $5 \%$, showed fixed effect model was superior to the mixed regression model.

In the choice of fixed effect model or random effect model problem, we should see whether the intercept of the stochastic model and explanatory variables are related. Hausman (1978) proposed test methods for testing. The test results showed that the probability of the chi-square statistic is less than 0.05 , rejecting the null hypothesis and assuming that the equation does not have a random effect.

TABLE II. ESTIMATION RESULTS

\begin{tabular}{|l|l|l|l|l|}
\hline Variable & \multicolumn{1}{|c|}{ Coefficient } & \multicolumn{1}{c|}{ Std.Error } & \multicolumn{1}{c|}{ t-Statistic } & Prob \\
\hline C & $-59.417^{* *}$ & 22.704 & -2.617 & 0.009 \\
\hline $\ln$ POP & $12.529^{* *}$ & 3.079 & 4.068 & 0.000 \\
\hline $\ln$ GDP & $0.470^{* *}$ & 0.141 & 3.325 & 0.001 \\
\hline $\operatorname{lnTRD}$ & $0.471^{* *}$ & 0.074 & 6.337 & 0.000 \\
\hline $\operatorname{lnDIS}$ & $-0.079^{*}$ & 0.047 & -1.685 & 0.094 \\
\hline CUL & $2.431^{* *}$ & 0.519 & 4.682 & 0.000 \\
\hline R-squared & 0.968 & \\
\hline Adjusted R-squared & 0.962 \\
\hline F-statistic & 161.346 \\
\hline
\end{tabular}

The empirical results showed the decision for China Southern Airline launching a new flight route is majorly based on the market demand, because the population is the most major influent variable in the model. The larger the population means the higher market demand for China Southern Airline to provide the flight service.

The traditional variables such as GDP and trade variables played a similar role on launching a new flight route. But the continuous increased in the GDP and trade showed that the along the Belt and Road countries, economic connectivity with China promoted transportation and accessibility of these Belt and Road countries, not only to the China but also to the World, and also could improve the living standard as the connectivity increased.

In "Belt and Road Initiatives", there is one part about "People-to-people bond" which asked to carry forward the spirit of friendly cooperation of the Silk Road by promoting extensive cultural and academic exchanges, personnel exchanges and cooperation, media cooperation, youth and women exchanges and volunteer services, so as to win public support for deepening bilateral and multilateral cooperation. The culture variable strongly showed the evidence of the importance of this "People-to-people bond" Initiative. The culture understanding and integration also could affect the travel demand and business exchanges significantly, and played a positive impact on aviation flights demand.

\section{CONCLUSION}

The "Belt and Road Initiatives" have provided great opportunities for China companies and other countries, esp. companies in infrastructure and transportation industries. China Southern Airline is a case who actively responded to the national initiative and provided strong support for the "Belt and Road" drive. China Southern Airlines is the main force of aviation connectivity, and has established a sound route network with the number of air routes, flight frequencies and market shares ranking first among domestic airlines, and has become China's Along the line countries and regions, including South Asia, Southeast Asia, South Pacific, Central and West Asia and so on which are mainly covered by the "Belt and Road".

For aviation companies like China Southern Airlines, the opportunities to build up the competitive capabilities are to drive "going global" strategy by "flying out" to countries and regions along the Belt and Road, exporting capital, products and services in a variety of ways including code sharing, airline alliances and equity investments, with a focus on airlines Enterprises, airports, maintenance, aviation food, service, ground service and other business cooperation, to expand tourism, logistics and finance. And aviation companies should actively carry out the navigation business cooperation with companies in Middle East, Southeast Asia and other regions along the Belt and Road.

\section{REFERENCES}

[1] Cohen, Shamai. (2016). A Gravity Model for Aviation Forecasting. . 10.13140/RG.2.1.1830.0401.

[2] O’Connor, W.E., 1982. An Introduction to Airline Economics, Third ed.Praeger, New York.

[3] Jorge-Caldero' n, J.D., 1997. A demand model for scheduled airline services on international European routes. Journal of Air Transport Management 3, 23-35.

[4] Doganis, R., 2004. Flying Off Course-The Economics of International Airlines, Third ed. Routledge, London, New York.

[5] Russon, M.G., Riley, N.F., 1993. Airport substitution in a short haul model of air transportation. International Journal of Transportation Economics 20, 157-173. 
[6] Jorge-Calderón, J.D.,1997. A demand model for scheduled airline services on international European routes. Journal of Air Transport Management, Vol. 3 (1), pp.23-35

[7] Grosche, Tobias; Rothlauf, Franz; Heinzl, Armin, 2007. Gravity Models for Airline Passenger Volume Estimation, In: Journal of Air Transport Management, Vol. 13, No. 4, 2007, pp. 175-183.

[8] Matsumoto, H., 2004. International urban systems and air passenger and cargo flows:some calculations. J. Air Transp. Manag. 10, 241-249.

[9] Matsumoto, H., 2007. International air network structures and air traffic density of world cities. Transp. Res. E 43, 269-282.

[10] Yamaguchi, K., 2008. International trade and air cargo: analysis of US export and air transport policy. Transp. Res. E 44, 653-663.
[11] Hwang, C., Shiao, G., 2011. Analyzing air cargo flows of international routes: an empirical study of Taiwan Taoyuan International Airport. J. Transp. Geogr. 19, 738-744.

[12] Industrial Cooperation between Countries along the Belt and Road, China International Trade Institute, August 2015

[13] Levin, A., C.-F. Lin, and C.-S. J. Chu. 2002.Unit root tests in panel data: Asymptotic and finite-sample properties. Journal of Econometrics 108: $1-24$.

[14] Im, K. S., M. H. Pesaran, and Y. Shin. 2003. Testing for unit roots in heterogeneous panels. Journal of Econometrics 115: 53-74.

[15] Maddala G.S and Shaowen Wu (1999)"A comparative study of unit root tests with panel data and new simple test”, Oxford Bullertin of Economics and Statistics, Special issue, 631-652. 